Ini Tanjung Tani and Moses Glorino Rumambo Pandin

Airlangga University

Jl. Airlangga No. 4-6, Surabaya, Surabaya City, East Java

ini.tanjung.tani-2020@ fib.unair.ac.id; moses.glorino@fib.unair.ac.id

\title{
Resensi Buku Alfred Schutz: Pengarusutamaan Fenomenologi dalam Tradisi Ilmu Sosial ( Book Review Alfred Schutz: Mainstreaming Phenomenology in the Tradition of Social Sciences)
}

Muhamad Supraja; Nuruddin Al Akbar; Yogyakarta; Year; 2020; ISBN Number: 978-602-386842-1; Number of Page: 222 page

\section{Introduction}

The book "Alfred Schutz: Mainstreaming Phenomenology in the Tradition of Social Sciences" discusses the figure of Schutz regarding his phenomenological methodology which is not widely discussed in the academic world. Schutz himself is an important philosopher and sociologist because of his theory in sociology and philosophy studies. In the world of philosophy, he is a figure who studies the Husserlian tradition of phenomenology. Meanwhile, in the world of sociology himself, Schutz chose to explore Weber's methodological project. With the methodology proposed by Weber, he seeks to develop an interpretive methodology as an attempt to counter the tendency of the positivism tradition of science. The book was written to provide a discussion of the phenomenological methodology by Schutzian, which Schutz pioneered. Through his methodology, he taught that every individual is present in the stream of consciousness obtained from the process of reflecting on daily experiences. This book focuses on explaining the phenomenological methodology by Schutzian which later can become a reference for academics in Indonesia in developing the Schutzian methodology for Indonesian academics. In addition, this book also introduces Alfred Schutz as a critical intellectual who is not widely known, but whose thoughts and contributions have an impact on the world of social science.

This book is written and aimed at Indonesian academics, especially in the realm of philosophy and sociology. Although the name Schutz himself lost to other philosophers, he had a very large contribution in the fields of philosophy and sociology, especially for science in Indonesia. The methodology adopted by Schutz has inspired many academics to read reality. It is evident from the many studies in Indonesia that use the phenomenology of the Schutz methodology. This phenomenology is used to read reality in society. As in research conducted by Ristia (2020), it was found that people have different opinions, this is due to the influence of the applied norms. These different opinions become absolute and become freedom by each individual. Research using the Schutz phenomenology method can also be used to explore types of phenomenology and ethnography. Research in the genre of "transcendental phenomenology" is a phenomenon outside the egos of the researcher because the source of truth can be obtained by direct observation of the natural surroundings.

The author presents a biography of Alfred Schutz, who was a unique and influential intellectual but little known. The introduction of the background, politics, and culture in Schutz can inspire readers to get inspiration on Schutz's life. In addition, by knowing his background, readers will be able to analyze how a Schutz gets his thoughts. Apart from the history of Schutz's travels, its also provides a brief biography of Husserll. Husserll himself was an influential figure who influenced Schutz's thinking, he himself had the aim of building a scientific basis for philosophy and phenomenology in social science. Schutz's thoughts on phenomenology did not stop there, especially regarding sociology. Schutz's ideas were also continued by his students, such as Schutz himself who inherited knowledge from Husserll. Peter Berger and Luckmann, Schutz's students who could be said to shine were also briefly discussed in this book. They are both known for their work entitled The Social Construction of Reality, which is a work inspired by Schutz. Apart from the two of them, George Psathas, a Schutz student, will also be discussed briefly. Psathas himself prefers to discuss empirical studies in phenomenology which will later be useful for building knowledge about individuals in the subjective world. 
The book is very important for many people to know, because Alfred Schutz himself was an intellectual who was quite influential in the development of sociology for both the western and non-western worlds (such as Indonesia). The phenomenological study put forward by Schutz itself is a study that can be used by academics, especially sociologists to examine cases and realities in society. Indonesian sociologists and anthropologists can also apply Schutz's methodology and phenomenology studies to research Indonesian society. Indonesian academics have the opportunity to contribute to the scientific space globally to continue developing Schutz's ideas and thoughts. By reading the book, academics and readers will get inspiration from Schutz's thoughts that have been described. Indonesian academics have the opportunity to be involved in global academic activities. So that it is the right choice for academics (social science) to read and implement the knowledge that has been obtained into existing cases and realities.

\section{Review}

The book is suitable for academics or readers from the social science field. The contents of this book describe the biography, phenomenology of Schutz, phenomenology in sociology, and several brief biographies about Hussrell and Schutz students who inherited their knowledge. A briefly written biography of Schutz can explain Schutz's background in detail and detail, from Schutz's birth, education, Schutz's life and the environment that influenced his thinking. Its also introduces phenomonology which Hussrell originally introduced. In which Hussrell himself became the successor of Hegel's phenomenological ideas. Phenomenology as a theory as well as a method is densely explained its origin and development. The book also discusses research methods using qualitative methods of phenomenology Schutzian. Not only an explanation, the writer also provides an example of how the phenomenological method is used to discuss reality in life.

"For example, when researchers reveal the meaning of poverty in Kendeng residents who are known for their resistance to rejecting industrialization in their area ..." (p. 159). With examples and an introduction to the explanation of the Schutz phenomenology method, readers will easily understand the content and purpose of phenomenological explanations. This book meets the needs of readers and is suitable for use by academies of social science to understand what phenomenology is, especially for those who first want to know what phenomenology is and get acquainted with Alfred Schutz himself.

In addition to the phenomenology and introduction to Schutz, its adds new information about the social science of the perspective of Jewish thinkers. This, of course has to do with wellknown western philosophers, most of whom are of Jewish blood. The author intends to analyze the Jewish thinkers whose ideas and ideas are more global than other thinkers. The author argues that why other thinkers are less legendary than Jewish thinkers is due to a lack of critical attitude and an excessive sense of inferiority on the one hand or an excessive suspicion of modern social science, so that they will not dare to contribute to the development of social science in a sustainable manner. global. Schutz's background was able to inspire him to design an idea to get out of the root of the problem, even though it would be against the social order system at that time. The author emphasizes that this understanding of Jewish thinkers can be taken as an example and can be implemented by other thinkers, especially Indonesia.

"As an illustration, in order to make it easier for us to get on Marxism. Marx's theory is not static, but dynamic. The classical Marx theory is constantly being interpreted by academics who claim to be Marxian ..."

(p. 53)

Basically, Marx got his ideas and ideas from the state of society at that time. It was the experience experienced by Marx that finally gave rise to his phenomenal ideas. A person will not be able to influence or direct the process of social change, unless he learns to understand the development and awareness of their existence. This is because it was not the psychoanalysts who developed it, but general experiences that gave the person awareness, giving rise to will and consciousness, thus giving birth to new theories. This can motivate academics to be more critical of the experiences and conditions of society so that they can turn these experiences into a perspective or a method of thinking. 
The book had a major influence, especially on social science academics, to deepen the thought of Alfred Schutz. This influence is in the form of views and ways of thinking of Schutz, a Jew who can make the experience and reality of life as a method. After readers read this book, they will certainly think more critically about social phenomena that occur in society. Not only Schutz's experience, the author also discusses Jewish thinkers who still exist today, their life experiences can be emulated by academics to be more critical and open to social problems that are in front of their eyes. It is these views and thoughts that will have an impact on readers, so that they can be embraced in the academic world globally.

The author himself influences readers with Schutz's passion and thoughts. The author also provides an analysis of the thoughts of Jewish leaders who have survived in a world that has different times. If the book is read by social science academics, it will be very appropriate because the ideas written will open minds to be more critical. The discussed Schutz methodology will inspire academics to be more active in conducting cross-scientific dialogue because this is still rarely done in Indonesia. This scientific dialogue will change our perspective. This scientific dialogue is more significant in the third world academics with the western world. Western thoughts are fixated on Jewish thinkers and create open spaces for other thinkers from outside the western world.

An author of the book presents evidence regarding Schutz's method of phenomenology in the chapter on the development of the phenomenological tradition in sociology. The author immediately provides an example of the use of the social research methodology with the development of Schutzian-style qualitative-phenomenological research. The author also provides tables about the different directions of sociological development according to Durkheim, Marx, and Weber. In addition, the author also presents another table about the different ways of thinking of Marx, Weber and Durkheim regarding the perspective of sociology. This supports and reinforces the differences between Schutz and other thinkers. In this chapter the author also describes Schutz's contribution in identifying social action that goes beyond Marx and Weber. Here, Schutz himself provides a new analysis that complements Weber's impasse. Schutz himself argues that Weber's ideas are vague and inconsistent. Regarding this, the author also explains by using a table about the differences between Shutz and Weber in the development of the sociological tradition. This book is complete enough to discuss Alfred Schutz and his theoretical origins. Because even though the author introduces Schutz briefly, the ideas and explanations given are quite complete and easy to understand for readers, especially for readers who know Schutz for the first time. The references used by the authors are also relevant because they use literature published in the last 10 years. In addition, the examples given by the author reinforce the phenomenological method in solving social cases.

The following is a proof quote from a book that applies Schutz's phenomenological method to a case.

Examples of research based on Schutzian Phenomenology Logic: The Japanese "Hikikomori" Case; "The reasons for raising the Hikikomori case are as follows:

1. There has been a review of "hikikomori in the Schutzian scheme as contained in the journal Schutzian research."

2. Hikikomori is closely related to the pace of modernism that is sweeping Japan and the world.

Hikikomori can be viewed as a social act even though in its form it tends to be asocial.

The solution that can be applied in the hikomori case is related to the subworld that is the base and the oppressive way of being. The way of being that prioritizes conformity in the style of modernism does not provide a comfortable space for hikikomori individuals to live their lives.

So far, with the book author provides new insights that are indispensable for readers to get acquainted with Schutz, especially with his methods of social phenomenology. In addition, this book is light enough to read for new readers who want to get to know Schutz and his theory.

The author presents briefly in light language about Schutz's biography as well as case examples using the phenomenological method that are easy to understand, this is the hallmark of this book. References and references are also made with footnotes that make it easier for readers to immediately understand the explanation presented. In explaining the theory, the writer also compares Schutz's superiority with other philosophers or sociologists using a short table. Examples 
of application in using the Schutz social phenomenology method are also described in detail in sentences that are easy to understand for readers.

The book discusses Alfred Schuzt and his social phenomenology methods which will certainly be of great interest to academics, especially those who are involved in the social world. So, not everyone will be able to understand or be interested in the discussion in this book, because it is a little heavy. However, for those who have jumped into the social world, this book becomes interesting and is a new knowledge about Schutz that is not widely known.

This is highly recommended for reading by academics, especially students from social science as a reference and new knowledge. The author does not only describe the birth of Schutz, but how he can get his thoughts through the experiences he gets. In addition, in this book the author provides an inspirational picture of the thinking of the western people, especially the advanced Jews. This can be used as motivation for readers to become critical and perceptive personalities with the social conditions around their life environment so that academic science (especially in Indonesia) can globalize and be able to compete with the science of western thinker figures in the future. A few brief points in this book regarding Hussrell's relationship with Schutz or other figures who influenced Schutz can be made broader. In addition, a discussion of social science and the domination of Jewish thinkers can be discussed on its own because the discussion is interesting and can inspire readers for great Jewish thinkers (not to be racist but to be used as inspiration and motivation for academics about how these thinkers are. with the idea that it is still relevant and studied in modern life today)

Ini Tanjung Tani dan Moses Glorino Rumambo Pandin Airlangga University

\section{References}

1. Supraja M. Alfred Schutz : Rekonstruksi Teori Tindakan Max Weber. Jurnal Pemikiran Sosiologi. 2015;1(2):81.

2. Supraja M, Al Akbar N. Alfred Schutz: Pengarusutamaan Fenomenologi dalam Tradisi Ilmu Sosial. 1st ed. Yogyakarta: Gadjah Mada University Press; 2021.

\section{AUTHOR SHORT BIODATA}

Dr. Muhamad Supraja was born in Baturaja, South Sumatra, Completed his undergraduate education at the Faculty of Law at the Indonesian Islamic University (UII) Yogyakarta in 1993 and the Department of Sociology at Gadjah Mada University in 1995, then the Masters of Sociology ( M.Si ) level was completed in 2001 and doctoral level in 2009 in the Sociology Postgraduate program. Faculty of Social and Political Sciences, Gadjah Mada University.

Nuruddin Al Akbar was born on July 26 in Yogyakarta. Currently, Nuruddin is an active student of the Doctoral Program in Political Science at the UGM Department of Politics and Government. 